\title{
Trump's New Face of Power in America
}

(updated and revised June 2021)

\section{Bob Hanke ${ }^{1}$}

York University, Toronto, Canada

\begin{abstract}
:
This article proposes that the advent of Trumpism was an historical moment of danger that compels us to analyze the micropolitics of the present. In the first part, I describe the constellation that gave rise to Trumpism. In the second part, I recall Goffman's concept of face-work and discuss how it remains relevant for describing Trump's aggressive face-work. In the third part, I take Deleuze and Guattari's concept of faciality as a point of departure for understanding microfascism. As an abstract machine, Trump's faciality engendered and diffused fascisizing micropolitics around a messenger/disrupter in chief. It worked in connection with a landscape and relative to a collective assemblage of enunciation that extracted a territory of perception and affect. In the micropolitics of the present, the defining feature of Trumpism was how the corrupt abuse of power and the counterforces limiting his potency collided on an ominous, convulsive political reality TV show that threatened US democracy.
\end{abstract}

Keywords: Trumpism, face-work, faciality, assemblage, micropolitics, impeachment, coronavirus pandemic

We are all sufferers from history, but the paranoid is a double sufferer, since he is afflicted not only by the real world, with the rest of us, but by his fantasies as well.

- Richard Hofstadter (1964)

When a man unprincipled in private life desperate in his fortune, bold in his temper, possessed of considerable talents, having the advantage of military habits-despotic in his ordinary demeanor - known to have scoffed in private at the principles of liberty-when such a man is seen to mount the hobby horse of popularity - to join in the cry of danger to liberty-to take every opportunity of embarrassing the General Government \& bringing it under suspicion-to flatter and fall in with all the non sense of the zealots of the day-It may justly be suspected that his object is to throw things into confusion that he may "ride the storm and direct the whirlwind."

- Alexander Hamilton (18 August, 1792) quoted by Rep. Adam Schiff (20 January, 2020) in his opening argument for President Trump’s Senate impeachment trial

\footnotetext{
${ }^{1}$ Corresponding author: Bob Hanke, Department of Communication \& Media Studies, York University, Toronto, Canada E-mail: bhanke@yorku.ca
} 


\section{Introduction}

2016 was a tumultuous year in US politics and the turmoil continued since Donald Trump was elected president. His rhetoric and demeanor in the political theatre of struggle prompted a range of views on whether fascism has already happened, is on the rise, or cannot happen in the US. In this debate, the difficulty is that whatever fascist traits we see, echoes we hear, or themes we interpret, depends on how we define "fascism.” Paxton (2005) tackled the problem of definition and noted that the language and symbols of a future, popular American fascism need not resemble historical European fascism. Amid all the chaos after Trump’s election, Grossberg (2018) claims that the similarities between Trump’s administration and fascism as a form of political behavior do not warrant the conclusion that he is a fascist. Paxton offers a comparative analysis of historical stages that begins in Europe while Grossberg emphasizes the cultural particularism of the contemporary US political context. Their accounts come close to converging when theorizing the link between choices, actions and "mobilizing passions" or political struggles and the "affective landscape.” Likewise, in a genealogical study, Connolly traces “aspirational fascism” by attending to affective flows of communication and contagion. His approach gives due weight to "multiple resonances between words, techniques, bodily demeanor, facial expressions, fears, images...” (Connolly 2017, p. 5). Colasacco (2018), however, suggests that fascism and Trumpism have a few features in common: "radicalism, populism, and perhaps above all, what Griffin calls 'palingenetic ultranationalism' (palingenetic denoting renewal or rebirth—or 'making great again')” (p. 28). Gounari (2018) describes a shift in discourse that took a "neofascist authoritarian turn” while Lebow (2019) and Morris (2019) make parallel cases that Trump’s “neoliberal authoritarianism” is best characterized as “inverted American-style fascism.” Relatedly, many 
other observers and commentators have noted how Trump's affective political communication promulgated post-truth politics, intensified political polarization, deepened fear and hostility, and encouraged violence.

What remains to be explored is how Trump's shock politics spread like a contagion in the direction of micro-fascism. One starting point is Deleuze and Guattari’s observation that "What makes fascism dangerous is its molecular or micropolitical power...” (1987, p. 215). If, as Guattari (2016, p. 104) suggested when he was working with Deleuze in the 1970s, "micro-fascist conjunctions of power can spring up all over the place," then this article proposes that such a conjunction sprang up in the US. In this conjunction, Trump's political performances are for all to see, read about, react to, and to rate. And as Garcia (2018) remarks:

Trump's political performance must be taken as a possible opening, as a symptom capable of generating ethical repositionings that would lead the American community to genuinely ask about its political order (p. 332).

Trump’s fascisizing micropolitics threw the US political order into disorganization so he could wield more power in the executive branch. In October 2019, House Democrats voted for a formal impeachment inquiry that led to a momentous vote on whether the president acted ethically and legally, or jeopardized the constitution by usurping Congressional power and undermining the system of separated powers. But after Senate Republicans acquitted Trump, it would be up to voters in the next presidential election and the courts to check and balance his efforts to consolidate power.

In the first part, I describe the constellation of Trumpism. In Benjamin’s (1969) sense, an historian "grasps the constellation which his own era has formed with a definite earlier one" (p. 263). Looking back at what happened, we can see how Trump’s politics surged up from historical 
tendencies and past events. But there was also a rupture in historical patterns and unprecedented presidential actions that disregarded democratic norms, rules, practices and laws. Going beyond the boundaries of other presidents, Trump learned to ride the storm and direct the whirlwind. As Adorno (2020, org. 1967) once warned, meteorological metaphors can naturalize the very real political problem of right-wing extremism.

In the second part, I revisit Goffman’s (1967a, org. 1955) essay “On Face-Work.” Trump’s style of aggressive face-work broke the ritual code and the result was sustained confusion and chaos. His repertoire of face moves arose from reality TV and a war model. Because his style was the message, the political impact carried far beyond his presentation of self; it induced micropolitical struggles, galvanized far right collective action, destabilized government, and set off stress tests for US liberal democracy. Guattari extends Goffman's insight that face-work makes impressions that matter to the faciality of power by analyzing faciality traits and refrains in the passage of desire.

In the third part, I draw upon Guattari’s $(2011,2016)$ theorization of "molecular fascism” and “faciality.” Understanding Trump’s new face of power, I suggest, can be enhanced by a dual focus on face-work and faciality. Both are inseparable from social interaction but the latter is derived from the film close-up of a face that gathers and expresses various affects (Deleuze 1986). Whereas Goffman approached expression as a microsociological problem of ritual syntax, social roles and order, Guattari's micropolitical approach to the mixed semiotics of expression problematizes 'the political matter of expression with which the group is confronted' (Guattari 2016, p. 61, italics in original). Through the concept of faciality, Deleuze and Guattari address the meshing of the micro and the macro, the interpersonal and the institutional, in collective 
assemblages of enunciation. Facial expressions do not just express individual selfhood and adorn spoken interaction; rather, ways of speaking, facial expression, gestures, and nonverbal components become pertinent when framed on the face. For Guattari, faciality traits are semiotic components of capitalist systems that play a "primordial role" through television in political struggles and presidential elections. They can enter into a "miniaturized formation of power" where "a faciality of power hangs over institutions and social relations of power” (Guattari 2016, p. 50).

According to Genosko (2018), the key to Guattari’s micropolitical approach is the relationship between mass desire and fascism. In the transition from classical fascism to "molecularized micro-fascisms, desire is at once liberated and subjected to repressive attributions tailored to new modes of production” (Genosko 2020, p. 173). Behind the appearance of Trump’s face, there is an abstract faciality machine that combines signification and subjectivation, and that arranges and connects flows of belief and desire. Once we find and outline this machine, we can ask how it works in connection with a landscape and relative to a right-wing assemblage that promotes a mode of enunciation. I go on to argue that Trump's faciality is on a path of molecular, micro-fascism with a multitude of black holes of subjectivation that resonate with each other. I conclude that Trump's televisual face-work and Twitter feedback/forward loops are coextensive with a faciality machine in a new era of right-wing, mediated populist politics. In closing, I deliberate upon the micropolitics of the present, and, as COVID-19 ravaged America, his final face-saving stratagem after losing the 2020 election. 


\section{The Constellation of Trumpism}

Trumpism challenges us to understand the constellation that set the stage for Trump's ascendancy to state power. Based on election day exit polls, the Reuters News Agency took the measure of his victory as “pure populism”; in his supporter’s eyes of desire for change, he was a "strong leader”... the “un-Obama” who would “Make America Great Again” by restoring the “Old America” (Schneider 2016).

Media and cultural studies scholars have linked Trump’s popularity, first campaign, and way of governing to reality TV, social media, self-promotion and branding (Hearn 2016, 2017; Schleusener 2020). As a real-estate tycoon who ran his business from the $26^{\text {th }}$ floor of Trump Tower in New York City, Trump played himself on The Apprentice (2004-15), a reality TV show that made him look presidential (Grynbaum \& Parker 2016). In his biographical trajectory from real-estate mogul to reality TV show producer and celebrity, his presentation of self and his brand became indistinguishable (see Figure 1).

In 2015, Trump transformed the set of The Apprentice into campaign headquarters for "the greatest infomercial in political history.” With the soul of a con man, he was the dealmaker who would negotiate better deals for America. As a court filing later revealed, while running for president, the Trump Organization communicated with President Putin’s office about building a Trump Tower in Moscow while Putin’s government was conducting a hacking and propaganda campaign to boost his candidacy. Trump was the first president to keep his assets in a familymanaged trust; during his conflict-of-interest ridden single term, his businesses took in billions of dollars, inflated his profits and hid his debts (Alexander 2020). 
As Ronald Reagan showed, there is power in acting (Massumi 2002). Trump’s celebrity persona reflects the logic of his reality TV show and the staged 'reality' of professional wrestling was a preview of his campaign. He was advised by Roger Ailes, the founder of the Fox News Channel who had advised Nixon, Reagan, and Bush Sr. His skill set for getting attention, which he developed in the 1980s New York tabloid press, and Fox TV's emphasis on visual presentation converged in Fox's coverage of the Republican primaries. Trump reportedly watched replays of his interviews with the sound muted (Concha 2016). His campaign was a movement of simplification and repetition against bad reality. Selling the fear of others and mistrust in government and the news media was primary. In his inaugural address, he presented his double vision of “This American carnage” and “America First.” In response to low presidential approval ratings, Trump returned to campaign mode to bolster his ego in front of cheering crowds. In his National Scout Jamboree speech on 24 July 2017, he lambasted "fake news” and "fake polls," railed against the “cesspool or sewer” of politics, and jokingly threatened to fire his health secretary. The next day at his sixth campaign-style rally since taking office, he boasted that "It's so easy to act presidential. But that's not going to get it done.” To outdo Reagan, "the great communicator,” Trump rejected the notion that "the President himself must be a skilled actor and that he must perform the role of the President rather than simply be President” (Meyrowitz 1985, p. 303, italics in original). With the West Wing as his TV set, Trump became the executive producer of his presidency.

US political populism has also been mediated by media convergence and the rise of social media (Hay 2011; Papacharissi 2015; Gerbaudo 2018). To stake his claim to political populism, Trump organized mass rallies in airport hangers, ate fast food, wore a baseball cap, and used 
Twitter to engage in the politics of debasement (Ott 2017). He was the first president to use Twitter to insert his statements into live TV news coverage, to drive and disrupt the news cycle and narrative, and to insult or troll people. His administration "mainstreamed cruelty as a daily political strategy” (Levina \& Silva 2018). On one hand, he is fascinated with his own image on cable TV news and obsessed with his TV ratings. On the other, here is Trump tweeting in February 2017 about the press and cable news channels: "The FAKE NEWS media (failing @nytimes, @CNN, @NBCNews and many more) is not my enemy, it is the enemy of the American people. SICK!” The exception is the right-wing media. Since 2011, Trump has enjoyed appearing on Fox TV. After he became president, the Fox-Trump partnership and feedback/forward loop grew stronger. As Hemmer (cited in Mayer 2019) argues, the cable news network "acts as a force multiplier for Trump, solidifying his hold over the Republican Party and intensifying his support.” According to Scherer (2017), Trump consumes his own presidency on a 60-inch flat screen TV with TiVo, feels wronged on TV, and enjoys doing play-by-play commentary in response to TV. After two years as president, he continued to view his presidency by TV ratings (Dawsey \& Kim 2019). Outside the right-wing media environment, the audience experiences The President Trump Show as an accelerated maelstrom of inaccuracies, lies, accusations, denials, leaks, investigations, scandals, spectacles, and crises.

In addition to these sources of Trump's persona and populism, we need to apprehend the wider historical context in which he came to occupy the White House. The 2008 global economic collapse was followed by stimulus packages, austerity agendas, and deepening inequality. In the US and Europe, an anti-globalization backlash combined economic anxiety, nationalism, and antiimmigration forces. The US right has been moving right since President Reagan, the first president 
and celebrity spokesperson of the “new conservatism” (Grossberg 1992). As Grossberg (2016) reminds us, it was Nixon that invented a politics of ressentiment that set "ordinary" folks against the socio-cultural elite. Trump updated the Republican Party’s “southern strategy” of using racial paranoia (Heer 2016). In Grossberg’s (2018) conjunctural story about the conservative battle for power since the 1950s, the Trump administration brought the war between the "New Right" and reactionary conservatives into the political and cultural mainstream. Through a Žižekian lens, Flisfeder (2018) describes the rise of the new "alt-right” and foregrounds the role of overlapping contradictions in postmodern practices of transgression and subversion, democratic and commercial logics of mainstream media, and the failure of the Left in the wake of the global financial crisis. Trump’s electoral victory was also due to other precipitating factors such as gerrymandering to create Republican districts, voter suppression, and Citizen’s United v. Federal Election Commission.

Trumpism evokes “Thatcherism” and “authoritarian populism” in Britain during the 1970s (Hall 1979). In the European context, Gandesha (2003) describes how "right-populist” discourse translates anxiety generated by globalization "into a determinate fear of a particular object... the figure of the 'stranger'” (p. 1). Since the 9/11 terrorist attacks, immigration and terrorism have been linked and Muslim populations in Europe and the US have been singled out. In response to the migrant crisis of the 2010s, nationalist and far right parties have made electoral gains in Europe. In the UK, Brexit's nationalist appeal and anti-immigration UK Independence Party were precursors of Trump's political rise. In the US context, Trump’s populism is rooted in the “paranoid style of American politics” (Hofstadter 1964), corporate “friendly fascism” (Gross 1980), American reactionary populism (Seaton 2017), American authoritarianism (MacWilliams 
2016) and "soft authoritarianism” (Beauchamp 2017). Regarding the role of television, Morgan and Shanahan (2017) found heavy viewers are "more likely to be authoritarian, and that authoritarians are more likely to support Trump” (p. 424). He exploited the polarization of party politics where differences in opinions reflect differences in individual's levels of authoritarianism (Hetherington \& Weiler 2009). White, male, older, less educated Trump voters shared his prejudices. Their wish for a domineering, aggressive leader who would punish the "undeserving" coalesced with the "wish for a reversal of what his base perceives as an inverted moral and racial order” (Smith \& Hanley 2018, p. 207).

"Build the Wall,” which began as a mnemonic catchphrase to help Trump remember to talk tough on immigration, became his premier campaign pledge. In his campaign launch speech, he expressed anti-immigrant sentiment when he said Mexico was bringing drugs and sending "rapists" and "killers" to the US. Such accusations bolstered this pledge even though only 3 percent of unauthorized immigrants have committed felonies (Chisti \& Mittelstadt 2016). During his presidency, his obsession with building a wall and fuming over the immigration crisis led to more extreme measures and border policies. Defying conventional wisdom and leaning towards anger about immigration, border security, and free trade, Trump amplified economic angst, racism, sexism, xenophobia, as well as fear of crime and gang violence.

According to Hochschild (2016), Trump was the "emotions candidate” who released himself and his crowds from "feeling rules" (p. 225, 227). She describes how the experience of unifying good people and scapegoating bad people in his rallies made people feel entertained and energized; consequently, the "desire to hold on to this elation became a matter of emotional selfinterest" (p. 228, italics in original). People joined him in jeering at foes and chanted "Lock her 
up” at Hillary Clinton. Quiet ressentiment towards the political system was transformed into the loud politics of hate (Browne 2016). Richardson (2017) argues that disgust was one of the affective drivers of his political success; as he puts it, "Performing disgust in train with the desire to Make America Great Again becomes a looping intensification of the desire for a return to the lost body politic” (p. 751). Compared to President Obama’s first inauguration, Trump’s election and inauguration signaled a shift in emotional regime towards "angry populism” (Wahl-Jorgensen 2018). Emotion and affect were mediated by pro-Trump media to shape the field of political possibilities. Picking up where the "Tea Party” movement of anger and distrust left off, the Trump campaign parlayed suspicion of Obama, hatred of the federal government, and white male identity politics into electoral victory.

The great subterfuge of Trump's populism is that rolling back Obama-era regulation combined with his budget proposals expressed his allegiance to rapid economic growth at any cost, plutocracy and the military. By pushing for more privatization, deregulation, and deep cuts to non-defense discretionary spending, Trumponomics is a part of a longer project to transform the liberal state-market nexus. In this false economic populism, the figure of the individual, white American worker who was left behind after the Great Recession and freedom from the federal government is conjoined with conservative ethno-nationalism and national self-interest in foreign policy.

After eight years of conservative claims about Obama’s “socialism,” Trump’s mythology of the "art of the deal" proved to be unsuited to the reality of working with Congress and foreign governments. Besides Trump’s own business interests and his cabinet of multi-millionaires and billionaires, there is Steve Bannon, an "alt-right” figurehead who believes the Judeo-Christian 
West and "enlightened capitalism" is in crisis and that "we are in an outright war against jihadist Islamic fascism” (Bannon 2016). He sees “globalists” as the enemy within and promotes the “deconstruction of the administrative state.” As CEO of Trump’s campaign, he tuned Trump’s message into “alt-right” grievances and fear of open borders. As Chief Strategist and Senior Counsellor for the president, he and senior immigration policy hardliner Stephen Miller influenced Trump’s travel ban on Muslims. For Bannon, immigration is connected to unfair competition for jobs from foreign labor and an issue to “carve out space” for a right-left populist coalition drawn from the 25 to 33 percent of left populist, economic nationalists (Bannon 2018). He exaggerated localized Islamist terrorism and believed Trump’s “economic nationalist” agenda would make America great again by getting John Maynard Keynes' “animal spirits” flowing in financial markets.

Within this constellation, Trump entered presidential politics and bet on the escalation of right-wing populism. Comparing close-ups of Obama’s and Trump’s faces on TV suggests the power of facial images that emit signs and invest affective energies. Between 2009 and 2017, Obama’s refrain of "Yes we can” became "No we can’t” and we saw the hope of "a more perfect union” drain from his face. The 2008 financial crisis defined his presidency and market deference limited Obamanomics to an adjustment of the neoliberal order (Peck 2010). For his presidential bid, Trump abandoned any faith in the unity of "the people” in favor of getting the many to help him get elected. Both he and "the people" were "victims" of establishment condescension. His is not the face of friendly capitalism; instead, it is belligerent, scowling, impudent, petulant, or malicious. If Reagan’s credibility was “exactly equal to his transparency and the nullity of his smile” (Baudrillard 1988, p. 34), Trump’s face has a “smile deficit” and a surplus of grimaces. For 
his base, his credibility is exactly equal to his anger and belligerence (Anderson 2018). In addition, his face is a "major component of his ability to orchestrate shame” (Schaefer 2020, p. 11); hence, the recirculation of preferred images of his face convert supporters' shame into a feeling of dignity. Embedded in his face, his words are an incessant flow of disjointed statements, fragments, asides and digressions. He speaks an emotive, demotic language that was already popular on talk radio, reality TV, and social media (Packer 2019).

As Showalter (2017) argues, Trump “incorporated the political aesthetics of reality television in his approach to governance.” He cast all the supporting roles and fired, or tried to fire, those in non-supporting roles. After writing his “You're Fired” letter to FBI director James Comey, he disclosed how the mediated political is personal; he fired Comey after watching him testify on TV because “He’s a showboat, he’s a grandstander.” After the Justice Department appointed special counsellor Robert Mueller to investigate Russian interference and possible collusion with the Trump campaign, Trump tweeted: "This is the single greatest witch hunt of a politician in American history!” It is enough for him to brandish his face as a boss or victim, become a little megalomaniac, and impose his style of politics. During his first impeachment, he cast himself as a victim of persecution and defender of democracy against corrupt House Democrats. Through the intermediaries of TV, his smart phone and Twitter, Trump's face became a macroface of national power and center of significance and subjectivation.

\section{On Face-Work}

In an essay on face-to-face or mediated contact, Goffman (1967a) describes how face-work produces an image of self and acts out a line that expresses his or her view of the situation and 
others. The self is doubly defined as "an image pieced together from the expressive implication of the full flow of events" and "a kind of player in a ritual game" (p. 31). Face-work "serves to counteract 'incidents' — that is, events whose effective symbolic implications threaten face” (p. 12). While mainly located in or on the body, a person's face, through “interpersonal agencies," can also be "diffusely located in the flow of the events in the encounter and becomes manifest only when these events are read and interpreted for the appraisals expressed in them” (p. 7). Since Goffman studied face-to-face interaction in the 1950s, there has been continuity of immediate spoken interaction and great transformation of mediated social interaction. But whether individuals abide by or break the rules, "something significant is likely to be communicated" (1967b, p. 51). Trump’s style of aggressive face-work is the message. As a repeat offender, his own face mattered more than the face of others. Moreover, his business and career conduct was based on a courtroom model whereby litigation was used to neutralize threats, defend aberrant behavior, and avoid damage or being punished. As for his political undertaking, Trump was not first figure of "reactionary conservatism" to break the rules and make political statements by performing incivility (Grossberg 2018, p. 12).

Goffman’s essay also describes the aggressive use of face-work when encounters or undertakings are less a scene of "mutual considerateness" than an "arena in which a contest or match is held" (1967a, p. 24). His consideration of "aggressive interchanges” for an audience is still somewhat applicable to political campaigns. Because Trump’s aggressive face-work and lewdness—as revealed by an Access Hollywood audio tape—gave him the worst pre-election image ever of any presidential candidate, with a Gallup 61 percent unfavourable score, pundits did not expect him to win. Against the odds, however, he scored points against his adversaries and 
made gains for himself by remixing popular culture and politics. As Kanzler and Scharlaj (2017) argue in their analysis of political communication after the invective turn, The Apprentice and Trump’s campaign were oriented towards the 'gamedoc,' a "genre of reality tv in which the competitive game dominates as symbolic form” (p. 319). The genre promises viewing pleasure in "spectacles of emotionally charged rivalry among contestants and the humiliation of those identified as losers” (p. 322). Relying on the symbolic logic of agôn, he denigrated opponents to valorize himself as a strong leader.

Despite winning the 2016 electoral college vote, Trump attacked the voting system as “rigged” because he lost the popular vote (Graham 2019). Beyond agonistic logic, Trump’s facework employed a war model. As the documentary Get Me Roger Stone (Bank, DiMauro \& Pehme 2017) shows, Trump’s political playbook was written by political strategist Roger Stone, who presumes there is no difference between entertainment and politics, and believes "in doing whatever is necessary to win short of breaking the law.” Stone's rules of the political game include: “One man’s dirty trick is another man’s civil political action,” “Attack, attack, attacknever defend," "Admit nothing, deny everything, launch counterattack," and "Nothing is on the level.” In the film, Jeffrey Toobin comments that: “...Roger Stone created Donald Trump as a political figure. There is no doubt that in tone, in affect, in profile, the Trump candidacy was a pure Roger Stone production.” Trump and Stone’s modus operandi can be traced back to the Red Scare prosecutor and notorious political fixer Roy Cohn. During the Republican primaries, he weaponised personal, economic and ethnic shame (Haslett 2016). On the campaign trail, he attacked black NFL athletes for protesting police brutality and racial injustice. In office, he renewed the culture wars to turn America into two warring camps with impassioned protestors and 
Trump supporters facing off against each other. Picking up from where the conservative war on so-called "liberal media" left off, he framed the media as the political opposition and led a hate campaign to attack "fake news" and "failing” news organizations (Rosen 2018). By imposing tariffs on other countries, he escalated trade wars, especially against China. To sustain the obsession with fossil fuels, his administration withdrew from the 2015 Paris Climate Agreement and waged war on climate science. After two years of turmoil, the government was shut down in a battle over the funding of his border wall. Trump was isolated in the oval office, watching TV, tweeting insults at Democrats, and scanning the headlines. In his words, "Can you believe this? I’m doing great, but it’s a war every day” (cited in Baker \& Haberman 2018).

Here it is important to expand upon Trump’s war on truth, that is, persuasion that draws upon the "repetition of Big Lies” for his political base to spread (Connolly 2017, p. 19). In retrospect, Ben-Ghiat (2021) qualified this by noting that a leader’s Big Lie "has traction only if the public has been fed many, many smaller lies.” Trump’s first press secretary's lie about “the largest audience to ever witness an inauguration” was an attack on the truth value of National Park Service aerial photographs of the National Mall before Obama and Trump were sworn into office. Since his inauguration, Trump’s lying worsened and it would take a database to keep track. According to Dale (2018), his “dishonesty density” increased over time. He made most of his false claims in speeches, the second most in interviews, and most of these were on Fox News. In July 2018, a CBS "Battleground Tracker Poll” indicated that 91 percent of strong supporters trust Trump for accurate information—more than friends, family and mainstream media. By August 2020, the Washington Post tallied 22,257 errant claims in 1316 days (Kessler, Rizzo \& Kelly 2020). In his first year, he averaged 6 a day; in his fourth year, he averaged 27 a day. His most 
repeated claim was that the US economy is the best in history and his second most repeated claim was that the border wall is being built. The novel coronavirus pandemic generated a new genre of falsehoods. Running against Joe Biden, Trump's barrage of false or misleading claims exceeded the ability of the fact checking team to keep up. It was left to White House press secretaries and surrogates to put a straight face on his lies, and to right-wing media to reinforce them. Meanwhile, journalists and late-night comedians mined the media archive of his statements to expose the falsehoods, contradictions or absurdities, and question his competence or mental state.

In Goffman’s terms, Trump was a non-self-regulating, self-aggrandizing candidate and president. His aggressive face-work took a hard line that only values winning. Despite his selfimage as the "best dealmaker," he gave the impression of falsely possessing the attributes he claims to have. As many political commentators often pointed out, he lacked the tone and temperament to act as president. Anger over what was done to his face functioned as a primary move. If, as Goffman noted, the main principle of a ritual order is not justice but face, Trump invested in his and insulated himself not only "by blindness, half-truths, illusions, and rationalizations” (1967a, p. 43) but also by serial lying, revisionist claims, evasion, retaliation, and disguising his politics as legal strategy. He expected others to display loyalty to his line or face dismissal or banishment. To be consistent with his political messaging, his former personal lawyer and 'legal fixer,' admitted he lied to Congress about a Moscow real estate deal “out of loyalty.” Aides and appointees discovered how selective and temporary his loyalty to them would be. The most striking feature of Trump's face-work was how frequently he broke the ritual code without making corrective moves. As president-elect, he called Twitter "his method of fighting back that's very tough.” Concerned about the political and legal implications of his Twitter battles in the 
context of numerous investigations, his advisors urged him to use restraint. But after Comey testified before Congress, he fought back on Twitter by calling Comey a liar and a leaker. For his supporters, his unscripted, off-the-cuff, style of public speaking and twitter tirades were signs of his authenticity.

In debates, interviews, and on \#realdonaldtrump, Trump engaged in the defacement of others and takes a defensive orientation to saving his own face. In his first 100 days, he was the topic in 41 percent of all news stories. He did most of the talking but set a new standard for unfavorable coverage. Consequently, "he's been on the defensive during most of his 100 days in office, trying to put the best face possible on executive orders, legislative initiatives, appointments, and other undertakings that have gone bad" (Patterson 2017). Later, he exercised presidential prerogatives and asserted executive privilege to push the constitutional limits of presidential authority to protect himself or his inner circle. As the Russia investigation widened into the Trump campaign, White House, and family, he tweeted about his "complete power to pardon.” His disinhibited, unruly performance changed the meaning of the oval office as a "bully pulpit' and raised questions about his adherence to the oath of office. His norm-breaking rhetoric has been analyzed as a "double-edged rhetorical identity and signature” (Jamieson \& Taussig 2017-18). Likewise, Trump’s presentation of presidential self deviated from conventional standards, protocol, custom, or precedent to disrupt political norms. His effort to introduce unfavorable information about others introduced more unfavorable information about himself. And in playing the political game, his reputation for bad play became part of the face he must play. 
"Power of any kind,” Goffman observed, “must be clothed in effective means of displaying it, and will have different effects depending on how it is dramatized" (Goffman 1959, p. 241). Before taking office, Trump told his aides to think of each day as an episode in a TV show in which he vanquishes his rivals (Haberman, Thrush \& Baker 2017). After he was elected, journalists waited for him to pivot and act presidential. After 100 days, his job performance was assessed by journalists in terms of a "steep learning curve” and "on the job training." His first meetings with foreign leaders indicate that his aides tried to teach him the rules of presidential conduct. Nothwithstanding any such advice, there were cycles of aggressive face-work, combative face-saving practices, and wars of words on Twitter. After the first impeachment inquiry against him began, his face-work became more brazen and his demeanor became completely unhinged. His confrontational face-work with the leaders of allies gave the US a reputation for being unpredictable and unreliable on the global geopolitical stage. As Tucker (2018) notes, the "individualism" of individual actors is not what it was in the 1950s when Goffman was writing about the "presentation of self," nor is personal politics what it was in the 1980s and 1990s. For Trump, transgressing the ritual code and breaking the political rules was a way to fight the power of the elite. And yet, because face-work is required to gain public recognition in the networked digital media environment, Goffman’s microsociological view of face-work still has some relevance for understanding mediated, socio-political interaction in the late 2010s.

\section{On Faciality}

Whereas Goffman’s microsociology drew upon Durkheim’s sociology of religion, Deleuze and Guattari's interest in micropolitics pays homage to Tarde. For Goffman, the individual is a kind of 
actor that does face-work to maintain face, save face, or make aggressive use of it, whereas in Tarde, subjectivation is centered on semi or unconscious imitation-suggestion and the propagation of beliefs and desires. On the basis of Tardean analysis of "imitative rays" and the flow of social encounters, events and desires, faciality is a political-philosophical problem of the consistency of the socius as "an affair of resonance" (Guattari 2016, p. 50).

As Deleuze and Guattari (1987) conceptualize it, "The face is a politics” (p. 181). From their viewpoint, faciality is an abstract machine that mixes significance and subjectivation. This machinic faciality is neither an envelope nor a mask, included in the body, or ready-made. Rather, it is engendered by a "white wall/black hole” system (Deleuze \& Guattari 1987, p. 168). Behind the gaze is a black hole "from which a central signification will irradiate all local significations" (Guattari 2016, p. 183). Multiple black holes can proliferate and echo around this empty point. Subjects do not choose faces, nor does the face engender social power, instead, it is the assemblage of power that requires the social production of face. Thus, faciality is a machinic, unconscious process that draws the body across this "holey surface” system. Moreover, “Certain social formations need face, and also landscape” (Deleuze \& Guattari 1987, p. 180, italics in original).

Following their approach, we can apprehend Trump’s macroface by outlining the abstract machine that produces subjectivity and channels mass desire in a confluence of subjective affects and machinic effects. For Deleuze and Guattari, the faciality machine is not just a site for the expression of mental or affective states; it is adjacent to signification and infrasubjective. Even though we may attribute it to the individual named "Donald Trump," Trump’s particular faciality is individuated but not individual. Furthermore, faciality is associated with a refrain, a 
“significative redundancy,” that is associated with a face and a voice (Guattari 2011, p. 109). Before Trump became president, he brandished the face of a boss during a job interview on TV and “You're Fired!” was a catchphrase of the times. As a president under investigation, on 23 August 2018 at 1:10 am., he tweeted his new double refrain "NO COLLUSION_RIGGED WITCH HUNT.”

Facialization has a pole of revolutionary potential and a "paranoiac, reactionary, and fascisizing pole” (Deleuze \& Guattari 1983, p. 366). At the molecular level of the politics of desire, this machine comes before formal power and there are liberatory and micro-fascist options. In this regard, Trump’s particular faciality took a rightest, micro-fascist direction. He posted new faciality traits for a president that some political crowds and TV audiences desired. In tandem with political rhetoric and representation, there were recharged molecules of fascism that give a direction to flows of desire in the social field.

Deleuze and Guattari explain how the abstract machine functions in two ways. First, the “black holes” act like a computer and a binary relation of “yes/no,” acquiescence or refusal. The black hole absorbs or rejects; there is sense or non-sense. Trump’s faciality machine worked within standardization to produce a steady repetition of binaries: winners/losers, real news/fake news, us/them, friends/enemies. The only thing that matters are binary effects: Is he winning or losing? Did he win the election or not? Is he in total control or not? Is someone or something American or foreign? The effect of binarizing reduction is this: You are either for Trump’s facevoice or you are for non-sense. Second, the machine is a "deviance detector" that computes “normalities.” Given a concrete face, the machine "judges whether it passes or not, whether it goes or not, on the basis of elementary facial units” (Deleuze and Guattari 1987, p. 177). For example, 
to rile up his base before the 2018 midterm elections, Trump tweeted that the caravan of Central American brown people seeking asylum has "criminals and unknown Middle Easterners mixed in" as if this was a reason to declare a national emergency. In this case, "[t]here are only people who should be like us and whose crime is not to be” (Deleuze and Guattari 1987, p. 178). Racism propagates waves of sameness so that the dividing line is not only on the US-Mexico border but internal to "signifying chains and successive subjective choices" (Deleuze and Guattari 1987, p. 178).

Deleuze and Guattari also understand faciality as a process of decoding the face from corporeal codes and overcoding by the Face—a "holey surface" system. By way of an unconscious, machinic operation, the face, head, hands, body, clothing, mannerism, and ways of speaking is drawn across the holey surface. A painting of Donald Trump by Stephen Lee Naish that hovers between the abstract and the figural illustrates this system (see Figure 2). In this painting of deformation, “Amerika” references Kafka’s unfinished novel. It is not a matter of making it resemble Trump's face but of the sense of intensity. A face has taken shape on the white wall, but it also begins to appear in the black hole. The cornerstone is the eye-nose-mouth triangle, that is, subjective black holes of affect. The face and head are facialized but so is the body, which is losing its form. This hasty, crude painting is less of a portrait and more of a map of contagious affects that radiate unconsciously outward. An unnatural, orange-faced, blond-haired, capitalist faciality had passed through the electoral system without being made over or cut off.

In his analysis of the semiotics of Trump’s body, Bennett (2016) notes that his body is a "semiotic salad, an assemblage of incongruous, clashing elements that would have normally been smoothed out and homogenized but instead slide over and jostle with one another, never quite 
cohering into a single figure.” Trump’s decomposed face may touch on other parts of the body, like his hands. His signature gestures are either precision moves—shape and pinch, palms out, pointing at people, slicing or wild gestures that register chaos. Thrusting his index finger out, he singles out people for approval or jabs at a target of his wrath. One could go on to decode particular body parts and gestures. For example, Hall, Goldstein and Ingram (2016) describe how his depictive hand gestures have entertainment value that accrues visual capital in celebritydriven, mediated politics. Arias-Benavides (2017) decodes his hands as discrete sign of virility and a fetish that operates on a mythological level to replace political acumen with "masculine" values. For Deleuze and Guattari (1987), however, the machine "performs the facialization of the entire body and all its surroundings and objects...” (p. 181). For example, Emad Hajjaj’s depicts Trump's blonde hair blowing in the wind and adhering to the Empire State Building, the Statue of Liberty, the bald eagle, and the flag (see Figure 3). Here we have a faciality trait that eludes the organization of his face and implies a landscape. This cartoon illustrates a molecular flow of desire that spreads like a contagion and connects to signifiers of America. From the side of signification, we can interpret body parts and gestures. But these diverse semiotic components cross interior reaction/action and exterior reaction/action. From the side of subjective resonance, faciality "functions as a centre of resonance for micro black-holes that exist at the level of diverse semiotic components” (Guattari 2016, p. 179).

Before Trump became a candidate, he tested the political waters as a white face leader by taking charge of the "birther movement" to reject Obama's face as the legitimate macroface of the presidency. On the campaign trail, Trump’s faciality became a locus for crowd passion. At rallies, he loves riling up the crowd to a frenzy, and their size and visibility on TV matters to him. Dean 
(2016) argues that the crowd's egalitarian discharge may revive the form of the party on the left. But with deepening cynicism towards politics, Trump's rallies showed how molecular semiotic energy can flow in the opposite direction. Embodying political rudeness, he thrilled supporters by attacking "political correctness," a shifting term for a vague enemy—liberals and progressives attempting to silence him (Weigel 2016). If the crowd is not just an aggregate of individuals but a force of its own, Trump encouraged physical responses to protestors and violence against reporters. The more critics assailed Trump, the more his avid supporters dug deeper to defend him (Peters 2018). To energize voters for the mid-term elections after the Judge Brett Kavanaugh confirmation battle in the Senate Judiciary Committee, he and other Republicans tapped into conservative rhetoric to characterize resistance to his presidency as an "angry left-wing mob" (Young 2018). During his reelection campaign, Trump increased the salience of street violence in “Democrat-run Cities” or “Joe Biden’s America” to appear as the 'law and order’ president while leading a hate movement and inciting violence.

Deleuze and Guattari further propose that faciality is correlated with landscape. What landscape, they ask, "has not evoked the face that would have completed it, providing an unexpected complement for its lines and traits?” (Deleuze \& Guattari 1987, p. 173). Supported by right-wing media, Trump scaled up outrage to a national-popular political level to make the "forgotten men and women of our country," the "people who work hard but no longer have a voice,” appear on the American landscape (Smith 2016). Hochschild's (2016) ethnography of Calcasieu Parish, Louisiana describes the landscape that would become "Trumpland.” For the people she interviewed, the American dream is a line on a landscape and some of the people perceive themselves as "strangers in their own land" somewhere in the middle of the line. But 
various others—Blacks, women, immigrants, Syrian refugees—have been cutting in. For these Louisiana strangers, the line has slowed down and stalled. As we later learned, economic fatalism and fear of cultural displacement were motivating factors for white, working-class voters (Cox, Lienisch \& Jones 2017). Trump’s crowds responded to his celebrity and reacted to each other's responses in waves of enthusiasm. His pledge to "Drain the swamp" was a war cry against the corrupt establishment in Washington. While crowd desire also manifested itself on the left in Bernie Sanders’s campaign to shake up the complacent Democratic Party, Trump’s faciality machine resonated at the level of molecular insecurity and crowd desire swung toward new rightwing extremism. In his eyes, his crowds looked like "the people" but, rather than a unity, "the people" is temporary, a multiplicity of scattered, singular intensities. This is why Trump returns to Twitter as his online platform of crowd desire and makes incendiary statements on TV to fire up his base. As his presidency sank into moral, diplomatic, constitutional and pandemic crisis, he watched politics on TV and used Twitter as a here-and-now medium of outbursts, blamecasting, and the instant takedown. Revising Deleuze and Guattari (1987), Trump’s face was a “veritable megaphone” (p. 179) with a Twitter account.

What remains to be considered is the assemblage that effectuated Trump's faciality machine. Trump's faciality machine depended on an assemblage that was a political force for disorganization. Deleuze and Guattari conceive of assemblages as arrangements of heterogeneous elements—bodies, actions, passions, all the means of expression. They speak "on the same level” as states of affairs, states of facts, and subjective states” (Guattari 2011, p. 14). Most importantly, they promote a mode of enunciation, and stake out and envelope a territory. A list of elements would include but not be limited to: Trump’s face-work, advisors, allies, campaign strategists, 
political advertising, Republican Party, Fox News, The O’Reilly Factor, Hannity, Fox \& Friends, Tucker Carlson Tonight, The Ingraham Angle, Lou Dobbs Tonight, Justice with Judge Jeannine, The Mark Levin Show, National Enquirer, Alex Jones’s Infowars, The Rush Limbaugh Show, Breitbart News Network, Drudge Report, The Daily Caller, Newsmax, Sinclair Broadcast Group, the Koch brothers (billionaire oil barons), Robert Mercer (a big-data billionaire who partly owns Cambridge Analytica), super PACs, ACU, NRA, white evangelicals, armed far-right militias, white supremacist organizations, conspiracy theory, r/The_Donald subreddit, micro-targeted ads on Facebook, and Twitter. This is the macro assemblage where right-wing political life is played out. The (re)arrangement of elements involves the interplay of new and old media. Fox News was established in 1996 to break what the Right perceives as the liberal stranglehold over politics. It became an established channel for molding audiovisual sensibility towards the Republican Party and conservative causes. As president, Trump treated Fox News like his own state-run, TV news channel; by the end of his term, he gave 119 interviews to Fox News and 0 to CNN. But he also made habitual use of what Guattari calls new “micro-equipment of semiotization” (Guattari 2016, p. 87), namely, Twitter to form or divert attention, weigh in on issues, and modulate preoccupations.

The above list cannot possibly represent the map of this assemblage, not to mention the articulation of multiple components, networks, constituencies, alliances, platforms, and paths to radicalization. It will have to suffice to say that through synthesis, this right-wing assemblage extracted a territory of perception and affect. Its function is not to make everyone agree but to articulate all the "material, semiotic, economic and social components that produce a collective desire, a group eros...” (Guattari 2016, p. 74). Another key point is that some components are 
centralised and hierarchized on Trump's faciality and refrains while others behave like a "killreality" by "thwarting the effects of resonance, by catalyzing a rhizome, by unraveling the globalization of redundancies of the face, everyday life, and landscape, while making refrains and mutant faciality traits work on their own account” (Guattari, 2011, p. 106). This collective assemblage of enunciation mobilises, connects and concentrates the energy of desire to reactive micropolitics. Trump's faciality responded to Obama's macroface with suspicion, and through this assemblage’s mode of enunciation, a "people” became attuned to each other by regular repetition. The intensity of oppositional forces between local versus federal government control and against the left ballasts the form of expression. Trumpism snowballed, took hold of desire, and stimulated gut-level attraction to his face-work. His tweets mixed policy and disinformation with fervor. Fox News mixed his political messaging with moral panics. White Christian anxiety about changing demographics appeared on the faces of hosts Tucker Carlson and Laura Ingraham for a mostly white middle and working-class audience. This massive assemblage is open to an array of small, far-right groups in niche assemblages where white rage, pride, and fear of replacement flows on social media (Ganesh 2020). On the farthest online fringe, QAnon's array of baseless conspiracy theories emerged from the anonymous imageboard 4chan and then moved to 8chan to protect Trump and his supporters from an alleged "deep state.”

Trump’s breakaway from the facial formula for a president triggered an upheaval in the Republican Party. Without ever holding elected public office, his primary campaign defeated his rivals. As the nominee, he departed from the Republican script by appealing to the worried, white working class. To undo Obama’s diverse “new majority,” he connected to Christian fundamentalism and neoconservative movements that were central to the Bush Jr. regime (Holland 
2008). In the last days, he campaigned in Democratic Party territory. As Shafer and Doherty (2017) explain, the national media missed the territory of the Trump surge because of changes in the American media map that produced the Clinton wave. In the shift from newspaper to Internet publishing, local newspapers continued their long decline and national media was concentrated on the coasts and in Democratic-leaning, urban counties. For conservative or independent voters in the "heartland," the 'media' in the media bubble trope was a synonym for "liberal" and "coastal." Despite losing the popular vote to Clinton, Trump redrew the electoral college map by only 79,646 votes in Michigan, Pennsylvania and Wisconsin. Trump’s faciality machine played against the semiotic power of the state, government bureaucracy, and 'liberal/leftist' media. With his face/voice, “[s]ense occurs through acquiescence to the faciality of power” (Guattari 2016, p. 189). At a molecular level, black holes captured assignable subjective affects. In the Republican convention presidential nominee’s speech, Trump said "I am your voice” (Smith 2016), and in the 2016 election, many people accepted Trump as their voice in their name.

His surprise victory was deemed a stunning repudiation of the establishment by the New York Times, but at the same time, this mutant faciality deviated too much, spun outside of common sense or violated the law, and a "whole machinery of rectification" was put to work (Guattari 2016, p. 189). For example, several executive orders and measures were blocked by judges. In October 2017, Mueller’s indictment of Trump’s former campaign chairman Paul Manafort signaled a new phase of the Russia investigation. On 22 April 2019, the redacted, 2volume, 448-page Mueller report described ten episodes where Trump or his campaign engaged in potentially obstructive behavior, including his effort to protect himself from investigation by firing Mueller. Barr published a 4-page letter to Congress and conducted a live TV news conference 
before the report was released that echoed Trump's refrain of no collusion. But when the report was released, it became evident that the Trump campaign sought Russian political “dirt” on Clinton, and that the 2016 election was altered by Russian hacking and leaking of Democratic Party emails and the Russian Internet Research Agency’s campaign to magnify divisions within the electorate. Emboldened by his Attorney General, Trump asserted executive privilege over the full Mueller report and underlying evidence while the House Judiciary Committee would hold Barr in contempt of Congress. In this political struggle between the executive and legislative branches, House Judiciary Committee Chairman Jerrold Nadler announced the time for testing whether the US republic would remain the same or change into a tyrannical form of government had arrived (Bade, Leonnig \& Zapotosky 2019).

\section{Micropolitics of the Present}

Juxtaposing face-work and faciality yields an analysis of the micro-fascist conjunction of power that sprung up around the $45^{\text {th }}$ president. Fleeting facial expressions and aggressive face-work in the social interaction order are semiotic components in assemblages where desire and micropolitics are fused together. From a microsociological perspective, it was not just Trump’s rhetoric that disrupted political norms but his style of aggressive face-work. Significantly, on the global stage, he had friendly, official exchanges with dictators and strongmen of the far right: Putin, Jong-Un, Erdoğan, bin Salman, Duterte, Orbán, al-Sisi, Modi and Bolsanaro. His face-work distinguished him from all previous presidents by agitating the micropolitics of desire. From the perspective of micropolitical analysis, Trump’s faciality machine functioned to concentrates the energy of desire, take hold of it, and channel it along a retrogressive vector. The right-wing 
assemblage makes possible a mode of collective enunciation that channels resentment and grievances into angry populism, conspiracy theories, and paranoid delusion. And yet, while Trump was less popular than past presidents, his Gallup 2017-21 term average was 41 percent.

Grossberg (2018) concludes his analysis of the reactionary right and reactionary countermodernity by suggesting that Trump’s “chaotic assemblage of conservativism” points us toward the "possibility of the emergence of an anti-political, 'alt-fascism"” that clears "the space for the dispersed power of a new 'popular corporatocracy'” (p. 133). However that vision may be, from a Guattarian perspective on capitalist societies, “fascism has already taken place/passed!” (Guattari 2016, p. 61, italics in original). Since the micropolitics of the present is a question of not only what has happened but also of what possible future is taking place in a micro-fascist conjunction of power, we can affirm both viewpoints. Within the right-wing assemblage, the name "Trump" refers to a faciality machine. From this angle, micro-fascism was a mutation, if not a new strain, that spread like a virus. But more than that, during his time in office, his conduct deteriorated, his hardcore fans became more fanatical, and this mutation became more dominant and ultimately coalesced on the Capitol.

An extraordinary low point was reached on 15 August 2017 when Trump held an impromptu news conference and insisted there was "very fine people" and "blame on both sides" after a white supremacist Unite the Right rally in Charlottesville, Virgina killed an anti-racist protestor and injured 35 others. The suggestion of moral equivalence sent out shock waves. But there were also regular outrage and response cycles, deflection, diversion or distraction to defend himself when threatened, and smear campaigns against political opponents. Wishing to make Democratic representative Ilhan Omar, one of the first two Muslim women ever elected to 
Congress, the face of the "Democrat Party," Trump retweeted doctored videos that combined footage of some of her words and dancing with footage of the 9/11 terrorist attacks to amplify Islamophobia. Along with Alexandria Ocasio-Cortez, Ayanna Pressley, and Tlaib Rashida, she is one of four progressive women of color known as "The Squad" who faced waves of harassment, hatred and death threats each time he attacked them. In 2020, after the police killings of Breonna Taylor and George Floyd triggered protests against police brutality, he not only violated Twitter's rules about "glorifying violence" but also declared himself "your president of law and order.” To support this pitch, he deployed the US park police backed by the National Guard to violently clear out peaceful racial justice protestors near the White House so he could walk to a church and hold up a Bible for a photo-op. In 2020, as the coronavirus spread across America, he lied about the pandemic and the federal government's response, politicized the science, and undermined public health. Trump's whirlwind became a deadly vortex. Contrary to the view that his appalling performance only makes him a weak president with a record of more debacles and failures than legislative wins, Green and Nader (2020) calculate the sum of his particulars as "deviant fascism American-style.”

In this micro-fascist conjunction of power, Trumpism shaped the "elective affinity" between post-truth communication and populist politics in a fragmented media environment (Waisbord 2018). He exceeded by far the sense of enmity towards the press that we heard when Nixon's secretly-recorded, private Oval Office conversations in the early 1970s were released. In a speech to the Annual Convention of the Veterans of Foreign Wars in Kansas City on 24 July 2018, Trump warned the audience: “It’s all working out. And just remember: What you're seeing and what you're reading is not what is happening,” which echoes George Orwell’s 1984: "The 
party told you to reject the evidence of your eyes and ears. It was their final, most essential command.” Regarding his administration's interactions with the White House press corps, the ritual of formal daily press briefings became monthly events, then more sporadic and shorter, before being halted altogether. To give Trump more control, they were replaced by impromptu, South Lawn “Chopper Talk” sessions in front of Marine One and cameras where Trump’s freewheeling face-work and voice could dominate the interchanges. If Trump could diminish the role of the press corps, if most mainstream reporting on the White House could be discredited, and if most evidence-based sources of information could be attacked as unreliable, then only he should be believed. The political decision here, besides avoiding transparency and accountability, is a refusal to be legitimated or lead by evidence. His rejection of science, lack of a national strategy, and pressure to reopen the economy during a global pandemic made America first in total coronavirus cases and deaths.

At the facialized centre of the Trump presidency, there was no sense of limits on his power. The more unspecified enemies became discernible and specified—as "criminal aliens" who were the internal and external enemy—-the more micro-fascism proliferated. In Trump's quest to build a border wall and push "zero-tolerance” immigration policies, he manufactured a crisis at the southern US border and proposed a solution that was illegal and inhumane to distract from the real humanitarian crisis in the northern triangle of Central America. Trump had the faciality traits of an authoritarian head without forging concentric circles towards national unity or unified collectivity. The conjunction of micro-fascism did not coalesce into a mass movement but his antidemocratic impulses transformed the microtexture of the White House and tilted micropolitics towards a reactionary pole. When he talked about "treason," which is punishable by 
death, he broadened the definition and accused Democrats and critics of being guilty of it. His style of politics was a contagion within the Republican Party with effects on political races, candidates, registered Republicans, and independent supporters. Trump’s cabinet and staff turnover as well as Republican followership in Congress enabled him to consolidate power in the presidency. As his own adviser on foreign affairs and national security, he ignored intelligence and politicized intelligence agencies. Breaking the norms for lifetime appointees set by Obama and Bush, his most enduring legacy will likely be a rightward-leaning federal judiciary (Ruiz, Gebeloff, Eder \& Protess 2020). The death of Ruth Bader Ginsburg gave Trump and Republican Senate majority leader Mitch McConnell the opportunity to nominate and confirm a third social conservative and “originalist” to the Supreme Court; before the end of his term, they installed more than 230 judges on the Federal bench to push the law rightward for generations. With McConnell as his endless enabler in the Senate, Trump was capable of passing the Tax Cuts and Jobs Act that favoured corporations and wealthy Americans but could not replace the Affordable Care Act.

Trump demonstrated time and time again that he was a messenger/disrupter-in-chief who does face-work for his base on TV and Twitter. But for many other Americans, seeing his face on TV was uneasy to unbearable and resistance was possible. Connolly (2017) suggests that “multifaceted democracy” with an "ethos of pluralism and pluralization” and an "assemblage of resistance” could limit “aspirational fascism.” Beginning with the first Women’s March, there was a movement in resistance. As Meyer and Tarrow (2018) write:

Trump’s inconsistent and often erratic behavior, his lack of deference to well-established norms, and his savage attacks on opponents made it possible for those in the Resistance to 
downplay their differences on tactics and ultimate goals—at least during the first year of his presidency. (p. 21)

The anti-Trump movement apparently affected the electoral process. In the November 2018 midterm elections, widely believed to be a referendum on an unpopular president, voter turnout was the highest on record and Democrats gained 40 seats in the House of Representatives.

With control of the House come oversight committee probes, subpoena power and more investigations. The Mueller report revealed that Trump's effort to obstruct justice failed because the former White House counsel and aides "declined to carry out orders or accede to his requests" to protect him and themselves. After Attorney General William Barr’s April 2019 press conference on the Mueller report, Trump blasted the "Crazy Mueller Report” on Twitter by using a Game of Thrones meme to send a political message. Both Trump and characters in the serial fantasy drama express distrust of elites and represent struggles over who will rule (see Figure 4). According to Mueller’s report, however, it was not yet "game over”; Trump was not exonerated, there was much incriminating evidence, and it is up to Congress "to determine the full scope of his alleged misconduct.” During his tenure, his (mis)conduct became subject to partisan politics and the law that defines "collusion,” “criminal conspiracy,” "obstruction of justice,” “endeavor to obstruct," "corrupt intent,” "knowingly” and "willingly,” "abuse of power," "high crimes and misdemeanors,” and last but not least, "impeachable offence.”

For Deleuze \& Guattari (1987), politics “operates by macrodecisions and binary choices, binarized interests" but political decision making "descends into a world of microdeterminations, attractions, and desires...” (p. 221). On 24 September 2019, Trump declassified the quasi transcript of his 25 July 2019 phone call to Ukrainian President Zelensky. On one hand, this phone 
call was about macrodecisions pertaining to US foreign policy interests and Ukraine’s national security. On the other, Trump’s decision making operated at a micro level. To many observers, he had disclosed a "quid pro quo" where Trump withheld military aid to pressure the Ukrainian president to announce investigations of the Bidens on TV. Months before the public heard of Trump’s “quid pro quo,” Sean Hannity and Fox News was a nexus of Trump’s shadow foreign policy maneuvers to energize his base and demonize Clinton and Biden. An intelligencecommunity whistleblower complaint (filed on August 12 and released on September 26) exposed far-right conspiracy theory inside Trump’s inner circle. His obsession with Ukraine conspiracy theories led him to use presidential power to establish an "irregular, informal channel of US policy-making" to withhold military aid for political favours that would benefit his re-election campaign.

By October 2019, the House was moving more rapidly toward impeachment. An October 8 Washington Post-Shar School poll showed that 49 percent of adults approved an impeachment inquiry to remove the president from office. A day later, even a Fox News Poll found that 51 percent of registered voters wanted him impeached. On 31 October 2019, House Democrats and Republicans voted 232 to 196 along party lines on a resolution to formalize the public phase of an impeachment inquiry.

Supplementing Deleuze and Guattari’s (1987) insight into the limit of power centers where power and impotence complement and reinforce each other, a defining feature of Trump’s macroface is how the corrupt abuse of power above the constitutional rule of law and the counterforces limiting his potency have collided on an ominous, convulsive political reality TV show. We have seen migrant children separated from their immigrant parents and detained in large chain- 
link 'cages,' torch-wielding white supremacists and neo-Nazis chanting "White lives matter” and “Jews will not replace us," the deadliest attack on Jews in a synagogue, attempted mail bombings of CNN and prominent Trump critics, and a surge in hate crimes related to race, ethnicity and ancestry. Beyond the sway of humanitarian impulses, the place where Trump really speaks his mind is Twitter. With more than 80 percent of Democrats and nearly 30 percent of Republicans endorsing an inquiry, he tweeted about his political persecution: "It was all just a continuation of the greatest Scam and Witch Hunt in the history of our Country!” On TV, his face-work veered between promoting his greatness and persistent aggressiveness, overt disagreeableness and casual menace. As Deleuze and Guattari (1987) observe: "It is always from the depths of impotence that each power center draws its power, hence their extreme maliciousness, and vanity (p. 226).

Throughout his tenure, we witnessed how Trump's "faciality of power" hung over the presidency and relations of power, aided and abetted by Republicans. When the televised spectacle of the House impeachment inquiry began on 13 November 2019, affective flows of communication flowing through the public hearings, the media and affective publics reached a peak. The inquiry delved into how absolute the power of the president is and to what extent the US remains a constitutional republic. On Twitter, on 15 November 2019, Trump attacked Ambassador Marie Yovanovitch in real time as she described to the House Intelligence Committee how he attempted to hijack foreign policy. Against all the evidence of pressuring the Ukraine to investigate his political rivals and efforts to block Congressional investigation, a leaked Republican memo revealed their impeachment committee members' plan to defend Trump was to say, in effect, 'there's nothing to see here.' In response to three top career professional's 
testimony, Republican Jim Jorden, Trump’s pugnacious ally and defender, insisted that “What you heard didn’t happen.”

On 19 December 2019, the House of Representatives voted on two articles of impeachment: On Abuse of Power, 237 house members voted Yea and 197 voted Nay; on Obstruction of Congress, 229 voted Yea, 198 voted Nay. This set the stage for the Senate impeachment trial led by McConnell and a debate over what constitutes a fair trial. Senators took an oath to do "impartial justice according to the Constitution and the laws" and then voted 51- 49 against witnesses. In the end, Republican senator's continuing fealty to Trump prevailed, senators voted on party lines, and Trump was acquitted. The failure to impeach the president based on evidence of serious misconduct revealed that Congress had lost its ability to limit the president's power; hence, with impeachment turned into a “cynical instrument of partisan warfare,” presidential oversight would be left to the 2020 election (Wehle 2020).

But even the magnitude of the first impeachment spectacle was diminished when Trumpism led the US into an intersecting public health catastrophe and economic calamity. During Trump’s re-election campaign, he went from downplaying to denying COVID-19. He also undermined trust in science by dismissing face masks; consequently, the non-use of masks became a predictor of support for Trump. Perhaps the most striking example of mediated demagogic facework came after Trump tested positive and was airlifted to Walter Reed National Military Medical Centre. Before leaving, despite 210,000 American deaths, he tweeted: “Feeling really good! Don’t be afraid of Covid. Don’t let it dominate your life.” In a defiant return to the White House, infected Trump stopped on the balcony in front of live TV cameras and photographers, took off his mask, posed, and walked into the West Wing despite a growing outbreak inside (see Figure 5). 
In the 2020 presidential election, deemed by the Washington Post to be a referendum on Trump's norm-breaking, Biden won the popular vote by more than 80 million votes. The results canceled The President Trump Show but did not neutralize Trumpism. Despite his inability to carry out the duties of his office and exposing himself to criminal prosecution, Trump received more than 74 million votes. During the interregnum, foreign threats to the integrity of 2016 election were matched by an internal threat as he refused to concede, disrupted the peaceful transition of power, and attempted to overturn Biden's victory. For his expanded, devoted base, Trump released a 46-minute Facebook video and took to Twitter to attack the integrity of a free, fair and secure election, which left supporters with the conviction they had been cheated. Rightwing media took up his social media messages and promoted election denialism. Trump’s final face-saving stratagem to cling to power and protect himself consisted of the Big Lie that Biden stole the election from him (which many Republicans adopted), purges, a Texas lawsuit and amicus brief to the Supreme Court to challenge election procedures in four states (seditious abuse of judicial process to invalidate millions of votes), litigation to contest election processes or overturn results (filing 65 cases and losing 64 times), soliciting election fraud from the Georgia secretary of state (to find enough votes to overturn his defeat), abusing pardon power, and ultimate loyalty test of Republicans (allegiance to Trump or the Constitution). Angry, disaffected and gullible Trump supporters who refused to accept his defeat responded by donating money to his campaign, leadership PAC and the RNC, and by rallying to "Stop the Steal."

In the post-election, hyperpartisan, divided states of America, Trump and loyalist Republicans, afraid of Trump and his voter base, attempted a procedural coup to disenfranchise citizens who mainly live in cities where minorities and immigrants live. The last episode of his 
reality TV show was staged for a joint session of Congress and could be titled "This American Carnage.” It was set in Washington and made for right-wing media and those who continued to believe the Big Lie. At the "March to Save America" organized by Women for America First on 6 January 2021, Trump, still afflicted by a fantasy of his "sacred landslide election victory,” became the inciter in chief and motivated mostly maskless supporters, including many who were already radicalized by viral disinformation and receiving calls to violence on unmoderated social media platforms, to march to the Capitol to "take back our country." He urged the crowd to "fight like hell," cheer on "brave” congressional Republicans objecting to the counting of electoral college votes, and to cast their ire on "weak" Republicans. With instigators from right-wing extremist groups, some marchers became rioters —an aggrieved, lightly-armed, almost all white mob— who confronted and overwhelmed Capitol police to storm the Capitol building and swarm inside, delaying the certification proceedings. Back at the White House, Trump watched domestic terrorism on live TV and attacked Vice-President Mike Pence for not having the courage to defy the Constitution and reject the Electoral College vote count. After the 4-hour siege with scenes of violence and vandalism, 147 congressional Republicans still voted to overturn the Electoral College election results. Hours after Trumpism had reached a peak of disorder, ferociousness and death, Biden was certified as president. In Trump’s binarized view, the terrorists were "great patriots who have been badly \& unfairly treated for so long." The next day he made a statement that framed the end of his presidency as the "greatest first term in history" and "only the beginning of our fight to Make American Great Again!” In the context of this violent insurrection and plans circulating online for future "armed protests," Twitter permanently banned his personal account with 88.7 million followers citing the "risk of further incitement to violence.” But Trump had 
already given a call to arms that resonated with what QAnon believers call "the Storm" to ride the whirlwind of mayhem and sedition to Capitol Hill.

With a legacy of impeachment and other ignominies, as well as policy failures that exacerbated the dual health and economic crisis, his presidency ended where it began, with Trump pushing voter or election fraud conspiracy theory. A second impeachment put him far beyond the pale of previous bad presidents. On 13 January 2021, the House of Representatives voted to impeach Trump for “incitement of insurrection”; 222 Democrats and 10 Republicans voted Yea but 197 Republicans, rather than abandoning Trumpism, voted Nay. Trump is out of office but the right-wing assemblage, MAGA movement, millions of Republican who absolutely believe the election was stolen, “alt-right” platforms, and far-right groups are still present. Following the assault on democracy, polls indicated 74 percent of voters said democracy is under threat while 34 percent of Americans said they no longer believe in democracy. Under Trump’s enormous influence over the Republican Party, micro-fascism is coalescing a shrinking minority of Republicans to fortify their dwindling party for minority rule. The micro-fascist conjunction of power around the $45^{\text {th }}$ president was an historical moment of danger that will have far-ranging, long-term political ramifications for US democracy. 


\section{References}

Adorno, T.W., 2020. Aspects of the new right-wing extremism. Polity, Cambridge, UK.

Alexander, D., 2020. Trump’s Businesses Raked In \$1.9 Billion Of Revenue During His First Three Years In Office. [WWW Document]. Forbes. URL https://www.forbes.com/sites/danalexander/2020/09/11/trumps-businesses-raked-in-19billion-of-revenue-during-his-first-three-years-in-office/ (accessed 12.21.20).

Anderson, R., 2018. President Trump’s Smile Deficit. World Suffering \& Compassionate Relief of Suffering. URL http://worldsuffering.org/president-trumps-smile-deficit/ (accessed 4.9.19).

Arias-Benavides, P., 2017. First as Farce: Symbolic Politics and Donald Trump’s Hands. Global Societies Journal 5, 125-144.

Bade, R., Leonnig, C., Zapotosky, M., 2019. Trump asserts executive privilege over Mueller report; House panel holds Barr in contempt [WWW Document]. The Washington Post. URL https://www.washingtonpost.com/politics/barr-to-trump-invoke-executiveprivileged-over-redacted-mueller-materials/2019/05/07/51c52600-713e-11e9-b5ca3d72a9fa8ff1_story.html (accessed 5.18.19).

Baker, P., Haberman, M., 2018. For Trump, ‘a War Every Day,’ Waged Increasingly Alone [WWW Document]. The New York Times. URL https://www.nytimes.com/2018/12/22/us/politics/trump-two-years.html (accessed 4.6.19).

Bank, D., DiMauro, D., Pehme., M., 2017. Get Me Roger Stone. Netflix.

Bannon, S., 2018. A Fareed Zakaria Special: The Steve Bannon Interview. [TV Broadcast] CNN. 
Bannon, S., 2016. Remarks of Stephen Bannon at a Conference at the Vatican - The American Catholic [WWW Document]. URL http://the-american-catholic.com/2016/11/18/remarksof-stephen-bannon-at-a-conference-at-the-vatican/ (accessed 6.15.17).

Baudrillard, J., 1988. America. Verso, London.

Beauchamp, Z., 2017. Experts on authoritarianism are absolutely terrified by the Comey firing [WWW Document]. Vox. URL https:/www.vox.com/world/2017/5/11/15611346/comeytrump-russia-authoritarianism (accessed 5.14.17).

Ben-Ghiat, R., 2021. Trump’s big lie wouldn’t have worked without his thousands of little lies [WWW Document]. CNN. URL https://www.cnn.com/2021/01/25/opinions/big-lie-benghiat/index.html (accessed 4.23.21).

Benjamin, W., 1969. Illuminations. Schocken Books, New York.

Bennett, B., 2016. Trump’s body. Global cinema. URL https://btbennett.wordpress.com/2016/11/18/trumps-body/ (accessed 11.4.19).

Browne, R., 2016. How Trump made hate intersectional [WWW Document]. Daily Intelligencer. URL http://nymag.com/daily/intelligencer/2016/11/how-trump-made-hateintersectional.html (accessed 6.14.17).

Chishti, M., Mittelstadt, M., 2016. Unauthorized Immigrants with Criminal Convictions: Who Might Be a Priority for Removal? [WWW Document]. migrationpolicy.org. URL https://www.migrationpolicy.org/news/unauthorized-immigrants-criminal-convictionswho-might-be-priority-removal (accessed 3.7.17).

Colasacco, B., 2018. Before Trump: On Comparing Fascism and Trumpism. Journal for the Study of Radicalism 12, 27-53. 
Concha, J., 2016. Chuck Todd: Trump watches replays of interviews with the sound off [WWW Document]. The Hill. URL https://thehill.com/homenews/media/312242-chuck-toddtrump-watches-replays-of-interviews-with-sound-off (accessed 4.12.17).

Connolly, W.E., 2017. Aspirational fascism: the struggle for multifaceted democracy under Trumpism. University of Minnesota Press, Minneapolis.

Cox, D., Lienesch, R., Jones, R.P., 2017. Beyond Economics: Fears of Cultural Displacement Pushed the White Working Class to Trump. Public Religion Research Institute. URL https://www.prri.org/research/white-working-class-attitudes-economy-trade-immigrationelection-donald-trump/ (accessed 8.1.17).

Dale, D., 2018. Trump has said 1,340,330 words as president. They're getting more dishonest, a Star study shows [WWW Document]. The Toronto Star. URL https://www.thestar.com/news/world/analysis/2018/07/14/trump-has-said-1340330-wordsas-president-theyre-getting-more-dishonest-a-star-study-shows.html (accessed 7.14.18).

Dawsey, J., Kim, S.M., 2019. Trump’s barometer for success following Russia investigation’s end- TV ratings [WWW Document]. The Washington Post. URL https://www.washingtonpost.com/politics/trumps-barometer-for-success-following-russiainvestigations-end--tv-ratings/2019/03/29/acfde264-524e-11e9-af351fb9615010d7_story.html (accessed 4.5.19).

Dean, J., 2016. Crowds and party. Verso, London.

Deleuze, G., 1986. Cinema 1: The movement-image. University of Minnesota, Minneapolis. Deleuze, G., Guattari, F., 1987. A thousand plateaus: Capitalism and schizophrenia. University of Minnesota Press, Minneapolis. 
Deleuze, G., Guattari, F., 1983. Anti-Oedipus: Capitalism and schizophrenia. University of Minnesota Press, Minneapolis.

Flisfeder, M., 2018. “Trump”-What Does the Name Signify?, or, Protofascism and the AltRight: Three Contradictions of the Present Conjuncture. Cultural Politics 14, 1-19, https://doi.org/10.1215/17432197-4312844

Gandesha, S., 2003. The Political Semiosis of Populism. The Semiotic Review of Books 13, 1-7.

Ganesh, B., 2020. Weaponizing white thymos: flows of rage in the online audiences of the altright. Cultural Studies 34, 892-924, https://doi.org/10.1080/09502386.2020.1714687

García, M.C., 2018. Deleuze’s Politics of Faciality: Trump and American Exclusion, in: Sable, M.B., Torres, A.J. (Eds.), Trump and Political Philosophy: Patriotism, Cosmopolitanism, and Civic Virtue. Palgrave Macmillan, Cham, Switzerland, pp. 331-343.

Genosko, G., 2020. Micro-Fascism in the Age of Trump, in: Gandesha, S. (Ed.), Spectres of Fascism: Historical, Theoretical, and International Perspectives. Pluto Press, London, pp. 164-176.

Genosko, G., 2018. Black Holes of Drugs and Politics, in: The Reinvention of Social Practices : Essays on Félix Guattari. Rowman \& Littlefield International, London, pp. 95-114.

Gerbaudo, P., 2018. Social media and populism: an elective affinity? Media, Culture \& Society 40, 745-753, https://doi.org/10.1177/0163443718772192

Goffman, E., 1959. The presentation of self in everyday life. Doubleday, Garden City, N.Y. Goffman, E., 1967a. On Face-Work, in: Interaction Ritual: Essays on Face-to-Face Behavior. Pantheon Books, Garden City, N.Y, pp. 5-45. 
Goffman, E., 1967b. The Nature of Deference and Demeanor, in: Interaction Ritual: Essays on Face-to-Face Behavior. Pantheon Books, Garden City, N.Y, pp. 47-95.

Gounari, P., 2018. Authoritarianism, Discourse and Social Media: Trump as the 'American Agitator,' in: Morelock, J. (Ed.), Critical Theory and Authoritarian Populism. University of Westminster Press, London, pp. 207-227.

Graham, D.A., 2019. Democracy, Interrupted [WWW Document]. The Atlantic. URL https://www.theatlantic.com/politics/archive/2019/01/trump-continues-to-attack-riggedelections/580030/ (accessed 4.7.19).

Green, M., Nader, R., 2020. The F-Word: No Other Way to Describe Trump’s Fascism 2.0. [WWW Document]. The Nation. URL https://www.thenation.com/article/politics/trumpfascism-republican-convention/ (accessed 12.17.20).

Gross, B., 1980. Friendly fascism: The new face of power. Black Rose Books, Montreal.

Grossberg, L., 2018. Under the cover of chaos: Trump and the battle for the American right. Pluto Press, London, UK.

Grossberg, L., 2016. Thinking Conjuncturally about Countercultures, in: Hermmann, A.F., Herbig, A. (Eds.), Communication Perspectives on Popular Culture. Lexington Books, Lanham, pp. 141-151.

Grossberg, L., 1992. We gotta get out of this place: Popular conservatism and postmodern culture. Routledge, New York. 
Grynbaum, M., Parker, A., 2016. Donald Trump the Political Showman, Born on 'The Apprentice’ [WWW Document]. The New York Times. URL https://www.nytimes.com/2016/07/17/business/media/donald-trump-apprentice.html?_r=0 (accessed 6.15.17).

Guattari, F., 2016. Lines of flight: For another world of possibilities. Bloomsbury Academic, London.

Guattari, F., 2011. The machinic unconscious: Essays in schizoanalysis. Semiotext(e), Los Angeles, CA.

Haberman, M., Thrush, G., Baker, P., 2017. Inside Trump’s Hour-by-Hour Battle for SelfPreservation [WWW Document]. The New York Times. URL https://www.nytimes.com/2017/12/09/us/politics/donald-trump-president.html (accessed 10.30.19).

Hall, K., Goldstein, D.M., Ingram, M.B., 2016. The hands of Donald Trump: Entertainment, gesture, spectacle. Hau: Journal of Ethnographic Theory 6, 71-100, https://doi.org/10.14318/hau6.2.009

Hall, S., 1979. The Great Moving Right Show. Marxism Today 14-20.

Haslett, A., 2016. Donald Trump, Shamer in Chief [WWW Document]. The Nation. URL https://www.thenation.com/article/donald-trump-shamer-in-chief/ (accessed 7.28.18).

Hay, J., 2011. "Popular Culture” in a Critique of The New Political Reason. Cultural Studies 25, 659-684, https://doi.org/10.1080/09502386.2011.600554

Hearn, A., 2017. Confidence man: Breaking the spell of Trump the brand. Soundings: A journal of politics and culture 66, 79-89. 
Hearn, A., 2016. Trump’s “Reality” Hustle. Television \& New Media 17, 656- 659, https://doi.org/10.1177/1527476416652699

Heer, J., 2016. How the Southern Strategy Made Donald Trump Possible [WWW Document]. The New Republic. URL https://newrepublic.com/article/130039/southern-strategy-madedonald-trump-possible (accessed 4.14.19).

Hetherington, M.J., Weiler, J.D., 2009. Authoritarianism and polarization in American politics. Cambridge University Press, New York.

Hochschild, A.R., 2016. Strangers in their own land: Anger and mourning on the American right. New Press, New York.

Hofstadter, R., 1964. The Paranoid Style in American Politics. Harper’s Magazine. URL https:/harpers.org/archive/1964/11/the-paranoid-style-in-american-politics/ (accessed 6.15.17).

Holland, E.W., 2008. Schizoanalysis, Nomadology, Fascism, in: Buchanan, I., Thoburn, N. (Eds.), Deleuze and Politics. Edinburgh University Press, Edinburgh, pp. 74-97.

Jamieson, K.H., Taussig, D., 2017. Disruption, Demonization, Deliverance, and Norm Destruction: The Rhetorical Signature of Donald J. Trump. Political Science Quarterly 132, 619-650, https://doi.org/10.1002/polq.12699

Kanzler, K., Scharlaj, M., 2017. Between Glamorous Patriotism and Reality-TV Aesthetics: Political Communication, Popular Culture, and the Invective Turn in Trump’s United States and Putin’s Russia. Zeitschrift für Slawistik 62, 316-338, https://doi.org/10.1515/slaw-2017-0015 
Kessler, G., Rizzo, S., Kelly, M., 2020. Trump is averaging more than 50 false or misleading claims a day [WWW Document]. The Washington Post. URL https://www.washingtonpost.com/politics/2020/10/22/president-trump-is-averaging-morethan-50-false-or-misleading-claims-day/ (accessed 12.23.20).

Lebow, D., 2019. Trumpism and the Dialectic of Neoliberal Reason. Perspectives on Politics 17, 380-398, https://doi.org/10.1017/S1537592719000434

Levina, M., Silva, K., 2018. Cruel intentions: Affect theory in the age of Trump*. Communication and Critical/Cultural Studies 15, 70-72, https://doi.org/10.1080/14791420.2018.1435080

MacWilliams, M., 2016. The One Weird Trait That Predicts Whether You're a Trump Supporter [WWW Document]. Politico Magazine. URL http://politi.co/1JanmwQ (accessed 4.16.17).

Massumi, B., 2002. The Bleed: Where Body Meets Image, in: Parables for the Virtual: Movement, Affect, Sensation. Duke University Press, Durham, NC, pp. 46-67.

Mayer, J., 2019. The Making of the Fox News White House [WWW Document]. The New Yorker. URL https://www.newyorker.com/magazine/2019/03/11/the-making-of-the-fox-newswhite-house (accessed 4.5.19).

Meyer, D.S., Tarrow, S.G., 2018. The resistance: the dawn of the anti-Trump opposition movement. Oxford University Press, New York, NY.

Meyrowitz, J., 1985. No sense of place: The impact of electronic media on social behavior. Oxford University Press, New York.

Morgan, M., Shanahan, J., 2017. Television and the Cultivation of Authoritarianism: A Return Visit From an Unexpected Friend. Journal of Communication 67, 424-444, https://doi.org/10.1111/jcom.12297 
Morris, E.K., 2019. Inversion, Paradox, and Liberal Disintegration: Towards a Conceptual Framework of Trumpism. New Political Science 41, 17-35, https://doi.org/10.1080/07393148.2018.1558037

Ott, B.L., 2017. The age of Twitter: Donald J. Trump and the politics of debasement. Critical Studies in Media Communication 34, 59-68, https://doi.org/10.1080/15295036.2016.1266686

Packer, G., 2019. The Left Needs a Language Potent Enough to Counter Trump [WWW Document]. The Atlantic. URL https://www.theatlantic.com/ideas/archive/2019/08/language-trump-era/595570/ (accessed 8.6.19).

Papacharissi, Z., 2015. Affective publics: Sentiment, technology, and politics. Oxford University Press, New York.

Patterson, T., 2017. News Coverage of Donald Trump’s First 100 Days. Shorenstein Center. URL https://shorensteincenter.org/news-coverage-donald-trumps-first-100-days/ (accessed 5.21.17).

Paxton, R.O., 2005. The anatomy of fascism. Vintage Books, New York.

Peck, J., 2010. Constructions of neoliberal reason. Oxford University Press, Oxford.

Peters, J.W., 2018. As Critics Assail Trump, His Supporters Dig In Deeper [WWW Document]. The New York Times. URL https://www.nytimes.com/2018/06/23/us/politics/republicanvoters-trump.html (accessed 8.2.18).

Richardson, M., 2017. The disgust of Donald Trump. Continuum: Journal of Media \& Cultural Studies 31, 747-756, https://doi.org/10.1080/10304312.2017.1370077 
Rosen, J., 2018. Why Trump Is Winning and the Press Is Losing. The New York Review of Books. URL https://www.nybooks.com/daily/2018/04/25/why-trump-is-winning-and-the-press-islosing/ (accessed 8.3.18).

Ruiz, R.R., Gebeloff, R., Eder, S., Protess, B., 2020. A Conservative Agenda Unleashed on the Federal Courts [WWW Document]. The New York Times. URL https://www.nytimes.com/2020/03/14/us/trump-appeals-court-judges.html (accessed 4.15.20).

Scherer, M., 2017. Does Trump watch too much TV? Reliable Sources. [TV Broadcast] CNN URL https://www.cnn.com/videos/tv/2017/05/14/rs-does-trump-watch-too-much-tv.cnn (accessed 5.14.17).

Schaefer, D.O., 2020. Whiteness and civilization: shame, race, and the rhetoric of Donald Trump. Communication and Critical/Cultural Studies 17, 1-18, https://doi.org/10.1080/14791420.2019.1667503

Schleusener, S., 2020. 'You’re Fired!' Retrotopian Desire and Right-Wing Class Politics, in: Dietze, G., Roth, J. (Eds.), Right-Wing Populism and Gender: European Perspectives and Beyond. transcript Verlag, Bielefeld, pp. 185-206.

Schneider, B., 2016. Americans don’t think Trump is qualified. Why they elected him anyway. [WWW Document]. Reuters. URL http://www.reuters.com/article/us-schneider-trumpcommentary-idUSKBN1342G9 (accessed 7.28.17).

Seaton, M., 2017. An American populist in the White House. Soundings: A journal of politics and culture 65, 10-22. 
Shafer, J., Doherty, T., 2017. The Media Bubble Is Real— And Worse Than You Think [WWW Document]. Politico Magazine. URL https://www.politico.com/magazine/story/2017/04/25/media-bubble-real-journalism-jobseast-coast-215048 (accessed 8.2.18).

Showalter, D., 2017. Donald Trump and the Political Aesthetics of Reality Television. Berkeley Journal of Sociology. URL http://berkeleyjournal.org/2017/06/donald-trump-and-thepolitical-aesthetics-of-reality-television/ (accessed 11.2.19)

Smith, D., 2016. Trump’s Republican convention speech: what he said and what he meant [WWW Document]. The Guardian. URL https://www.theguardian.com/us-news/nginteractive/2016/jul/22/donald-trump-republican-convention-speech-transcript-annotated (accessed 4.14.20).

Smith, D.N., Hanley, E., 2018. The Anger Games: Who Voted for Donald Trump in the 2016 Election, and Why? Critical Sociology 44, 195-212, https://doi.org/10.1177/0896920517740615

Tucker Jr., K.H., 2018. The political is personal, expressive, aesthetic, and networked: Contemporary American languages of the self from Trump to Black Lives Matter. American Journal of Cultural Sociology 6, 359-386, https://doi.org/10.1057/s41290-0170027-9

Wahl-Jorgensen, K., 2018. Media coverage of shifting emotional regimes: Donald Trump’s angry populism. Media, Culture \& Society 40, 766- 778, https://doi.org/10.1177/0163443718772190 
Waisbord, S., 2018. The elective affinity between post-truth communication and populist politics. Communication Research and Practice 4, 1-18, https://doi.org/10.1080/22041451.2018.1428928

Wehle, K., 2020. Congress Has Lost Its Power Over Trump [WWW Document]. The Atlantic. URL https://www.theatlantic.com/ideas/archive/2020/02/checks-and-balances-trump-hasswept-away/606013/ (accessed 4.13.20).

Weigel, M., 2016. Political correctness: how the right invented a phantom enemy [WWW Document]. The Guardian. URL http://www.theguardian.com/usnews/2016/nov/30/political-correctness-how-the-right-invented-phantom-enemy-donaldtrump (accessed 5.13.21).

Young, J.C., 2018. The myth of the angry mob [WWW Document]. The Washington Post. URL https://www.washingtonpost.com/outlook/2018/10/12/myth-angry-mob/ (accessed 12.12.18). 


\section{Figures}

Figure 1. Trump on his 2015 press tour for The Celebrity Apprentice, photo by Chris Pizzello, Invision, The Associated Press

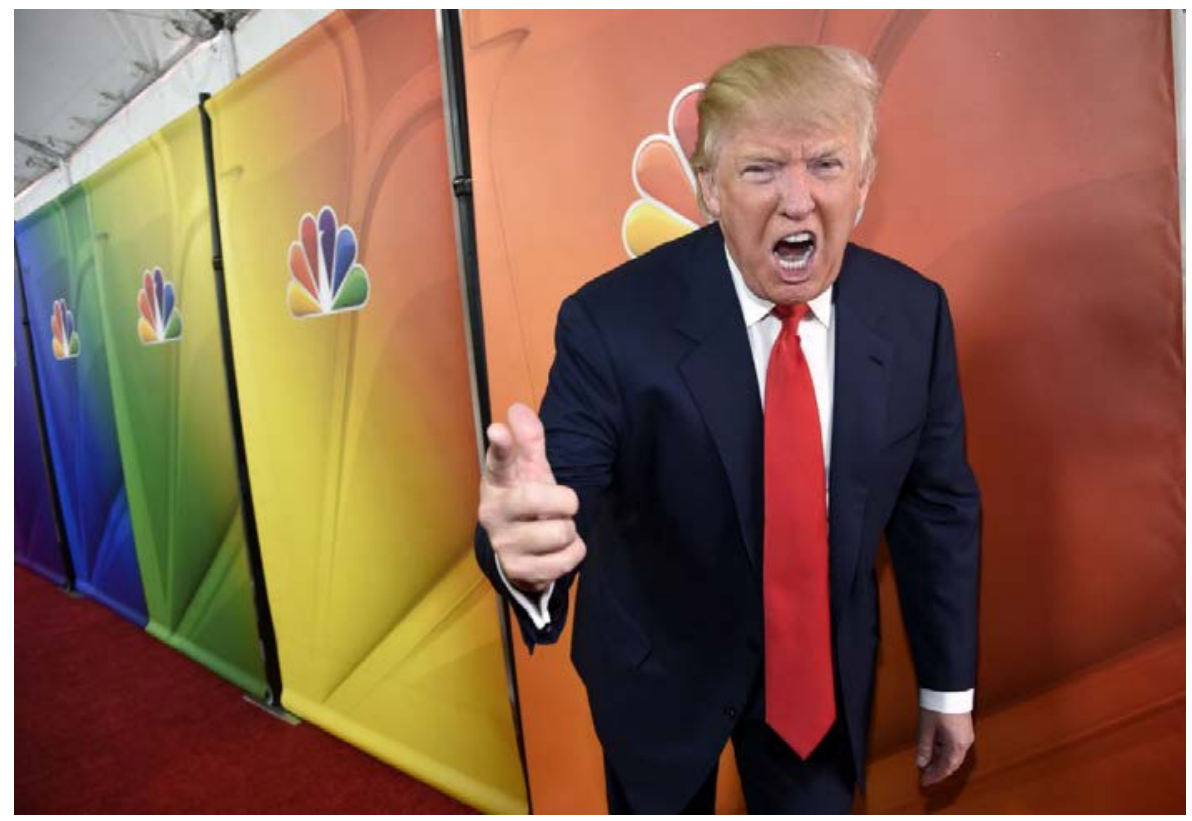


Figure 2. Painting of Donald Trump by Stephen Lee Naish

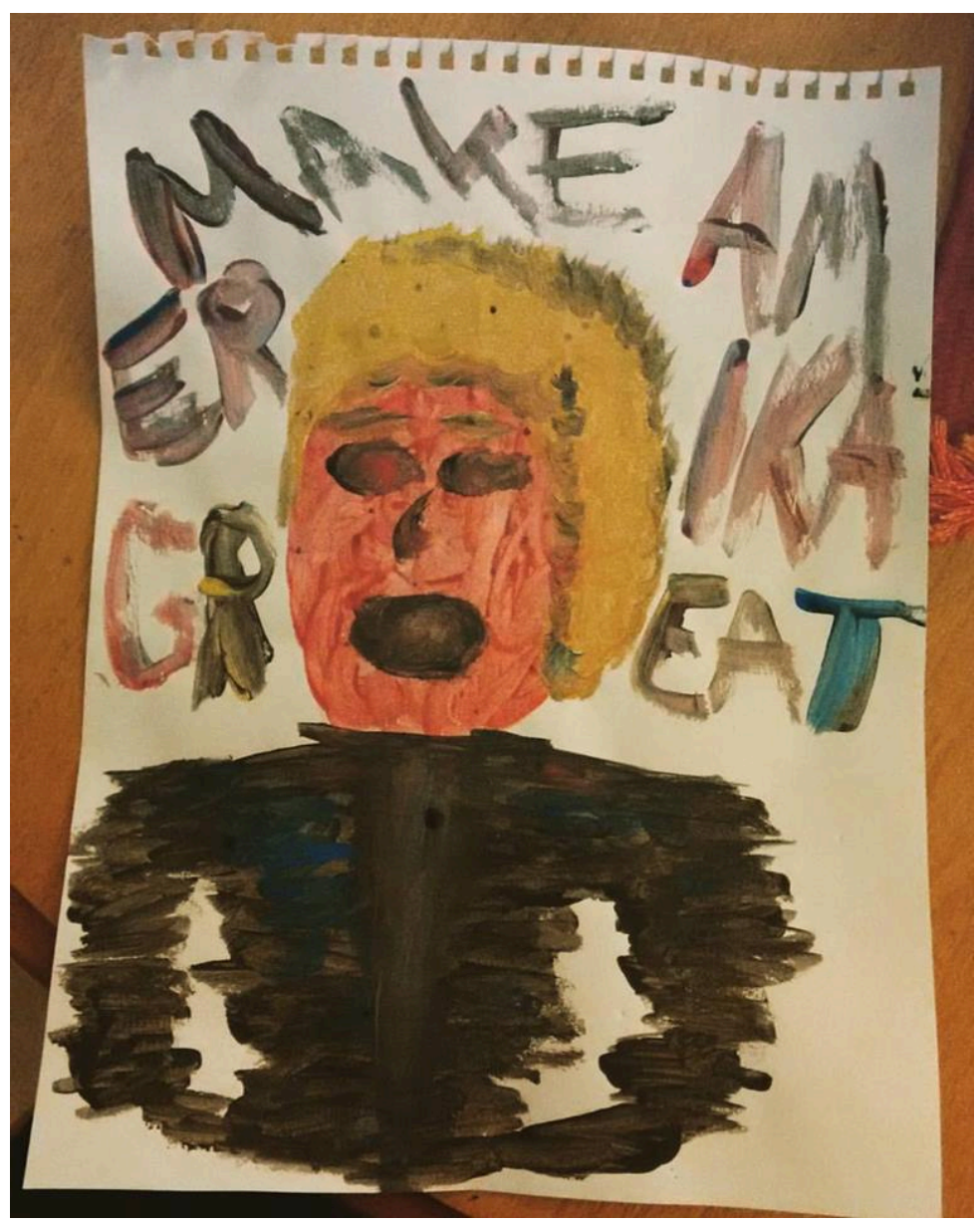


Figure 3. Trump's hair covers America and blows in the wind by Emad Hajjaj

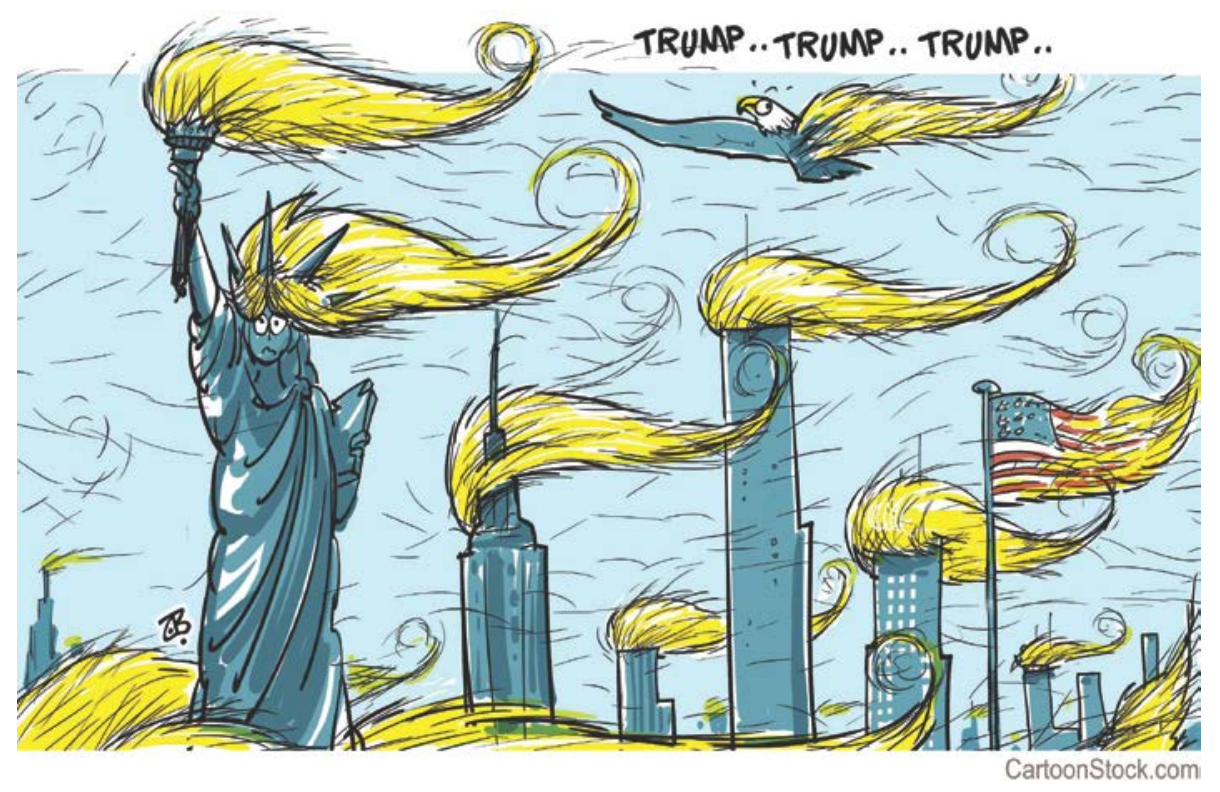


Figure 4. Donald J. Trump @ realDonaldTrump, Twitter, April 19, 2019, 8:18 am.

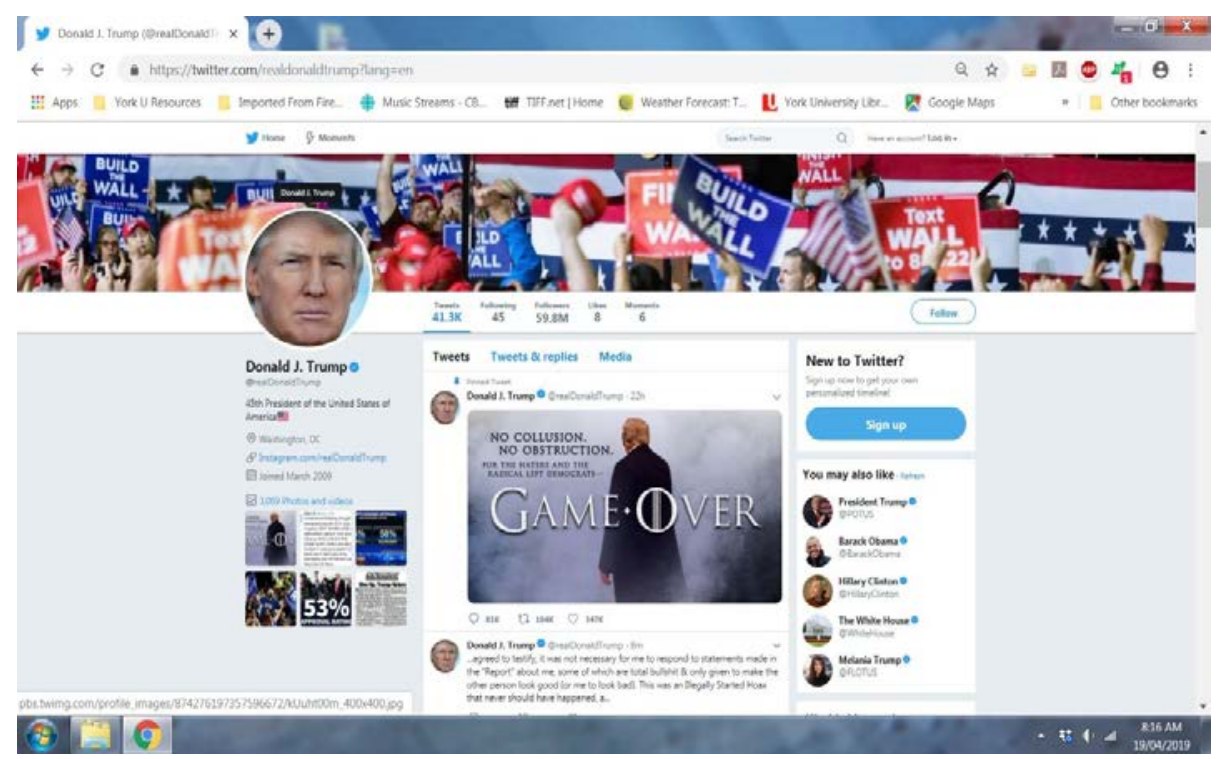


Figure 5. Trump Removes Mask on White House Balcony, photo by Win McNamee, Getty Images

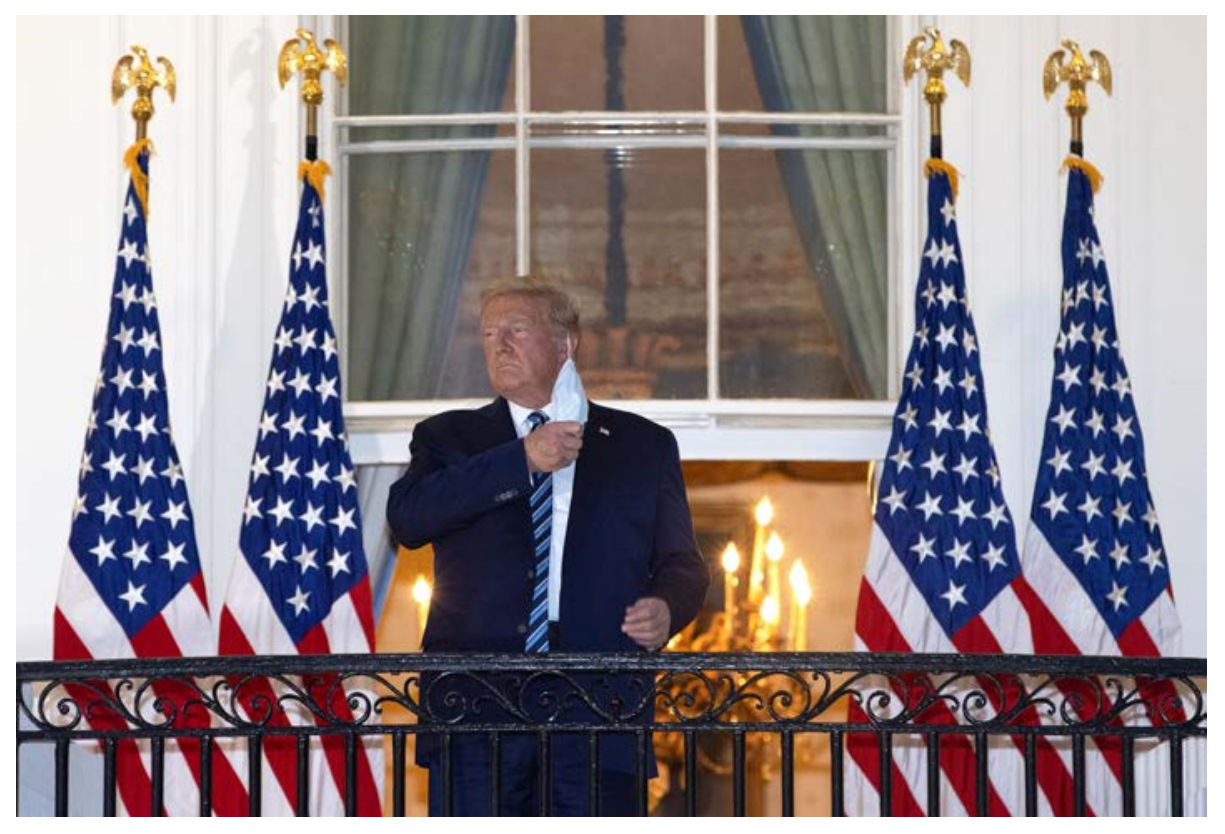

